\title{
Genetic Analysis of Quality Traits in Bread Wheat
}

\author{
Anjali Joshi*, Anil Kumar, Vartika Budhlakoti and Nidhi Bhatt \\ Department of Genetics and Plant Breeding, College of Agriculture, \\ Govind Ballabh Pant University of Agriculture and Technology, Pantnagar, \\ U.S. Nagar, 263145, Uttarakhand, India \\ *Corresponding author
}

\section{Keywords}

Bread wheat, quality traits, GCA, SCA

\section{Article Info}

\section{Accepted:}

08 January 2020

Available Online:

10 February 2020

\section{A B S T R A C T}

10 bread wheat genotypes were crossed in diallel fashion excluding reciprocals. The $F_{1} s$ and the parental lines were then utilised for combining ability analysis. Analysis of variance (ANOVA) showed the presence of significant variation for all four quality traits. ANOVA showed highly significant estimates of mean square for general combining ability for sedimentation value, hectolitre weight and phenol colour reaction however for protein content it was significant. Mean square for specific combining ability was highly significant for sedimentation value and phenol colour reaction while for protein content and hectolitre weight it was nonsignificant. Parental line UP 2762, KFA/2*KACHU and Raj 4419 showed superior general combining ability for more than one quality traits. On the basis of high per se performance and significant SCA effects in desired direction Raj 4419 x PBW 729, KAUZ/ALTAR84/3/MILAN/KAUZ/4/HUITES x UP 2762, PBW 729 x DBW 50 and Raj 4419 x NIAW 1594 were identified as superior cross combiners for protein content, sedimentation value, hectolitre weight and phenol colour reaction. These crosses can therefore be exploited commercially either in development of hybrid varieties with improved quality traits or in recovery of superior transgressive segregants which can be used for isolation of superior homozygous lines.

\section{Introduction}

Wheat is an important staple food crop grown throughout the world (Joshi et al., 2018) and forms an important constituent of Indian diet.Three species of wheat are grown in India. They include Triticumaestivum, $T$. durum and $T$. dicoccum.T. aestivum also called as the common/bread wheat covers 95\% area of the country (Joshi et al., 2018). It is ideal for making bread, biscuit, chapatti, cookies, noodles, cakes etc. $T$. durumcommonly referred to as macaroni wheat is grown in $4 \%$ area of the country and used for production of macaroni, vermicelli and spaghetti. A small portion i.e., $1 \%$ of the 
area under wheat cultivation in India is occupied by $T$. dicoccumand it is usedfor making chapatti, macaroni, spaghetti and also has medicinal value. Therefore, bread wheat is the most common type of wheat grown in Indian soils and form staple food crop of India.

The last few decades have observed increment in population at an alarming rate and in order to meet the requirement of growing population a number of high yielding wheat varieties have already been developed and work in this direction is still going on.

This is essential as by 2050 the world's population with a number of 9.1 billion will be higher by $34 \%$ than what it is currently and about $70 \%$ of the world's population will be urban. The income of people will increase many folds and therefore the urban and richer population will demand for superior quality consumable product.

The need of an hour is therefore, not only to develop varieties with higher yield but also to concentrate breeding efforts on quality improvement of wheat so that development of superior quality wheat varieties with sustained higher yields can take place. Wheat quality refers to its suitability for a particular end-use based on physical, chemical and nutritional properties of wheat grain (Joshi et al., 2019).

The present investigation was therefore undertaken with the objective to estimate the combining ability of parents and crosses with respect to four important quality traits in wheat. For improvement of wheat crop with respect to quality traits it is essential to identify whether genes controlling these traits acts in an additive or dominant manner.

This information will be helpful in deciding the breeding programmes for improvement of specific characters. The study also aimed to identify good general combiners and superior cross combinations in order to achieve improvement for quality traits by means of selection after hybridisation.

The performance of $F_{1}$ can be judged and superior parents for hybridisation can be chosen with the help of diallel method of combining ability analysis developed by Griffing (1956)

Therefore present investigation was conducted to identify suitable parents for hybridization on the basis of combining ability and per se performance and also to determine superior cross combinations for various quality traits which can be used for isolation of superior transgressivesegregants and development of improved variety to meet the needs of economically progressive urban population.

\section{Materials and Methods}

The study was conducted at Norman E. Borlaug Crop Research Centre, GovindBallabh Pant University of Agriculture and Technology, Pantnagar, India.

Ten wheat genotypes namely, QLD 39, KAUZ/ALTAR84/3/MILAN/KAUZ/4/HUIT ES, UP 2762, KFA/2*KACHU, Raj 4419, PBW 729, WH 1187, HD 2967, DBW 50 and NIAW 1594 having different desirable quality traits were crossed in half dialled fashion and $45 \mathrm{~F}_{1} \mathrm{~s}$ excluding reciprocals were produced. The $45 \mathrm{~F}_{1} \mathrm{~s}$ along with 10 parental lines and two checks viz., UP 2628 and WH 1105 were evaluated in randomized block design with three replications with each genotype planted in two rows of $1 \mathrm{~m}$ each with $20 \mathrm{~cm}$ spacing between rows and $10 \mathrm{~cm}$ spacing between plants and data was recorded with respect to four quality traits i.e., protein content, sedimentation value, hectolitre weight and phenol colour reaction. 
Table.1 Analysis of variance for general combining ability (GCA) and specific combining ability (SCA) for quality traits in wheat

\begin{tabular}{|l|l|l|l|l|l|}
\hline \multirow{2}{*}{$\begin{array}{l}\text { Source } \\
\text { variation }\end{array}$} & \multicolumn{6}{|l|}{ (Mean sum of squares of various characters } \\
\cline { 2 - 6 } & d.f. & $\begin{array}{l}\text { Protein } \\
\text { content }(\%)\end{array}$ & $\begin{array}{l}\text { Sedimentation value } \\
(\mathrm{ml})\end{array}$ & $\begin{array}{l}\text { Hectolitre } \\
\text { weight } \\
(\mathrm{Kg} / \mathrm{hl})\end{array}$ & $\begin{array}{l}\text { Phenol colour } \\
\text { reaction }\end{array}$ \\
\hline GCA & 9 & $0.977 *$ & $313.310 * *$ & $18.769 * *$ & $4.409 * *$ \\
\hline SCA & 45 & 0.644 & $132.593 * *$ & 4.259 & $2.684 * *$ \\
\hline Error & 108 & 0.456 & 4.126 & 5.929 & 0.377 \\
\hline
\end{tabular}

Protein content was determined with the help of NIT based Whole Grain Analyser (Infratech 1241 Grain Analyser). SDS sedimentation test recommended by Zeleny(1947) was used for determination of sedimentation value and hectolitre weight was determined with the help of hectolitre weight instrument.

Phenol colour reaction value of seed samples were determined by phenol colour reaction test which was conducted in four replication per sample.

100 seeds per replicate were soaked in distilled water for 16 hours. Thereafter the water was drained and $1 \%$ phenol solution was applied. The readings were taken after 4 hrs of application of phenol solution.Griffing's (1956) method 2 model 1 was used for analysis of combining ability and analysis was done with OP Stat software (Sheoron et al., 1998).

\section{Results and Discussion}

The data on four quality traits were analysed for combining ability and the estimates showed that mean square for general combining ability was highly significant for sedimentation value (313.310), hectolitre weight (18.769) and phenol colour (4.409) reaction however for protein content $(0.977)$ it was significant.
Mean square for specific combining ability was highly significant for sedimentation value (132.593) and phenol colour reaction (4.409) while for protein content (0.644) and hectolitre weight (18.769) it was nonsignificant (Table 1).

The presence of significant mean square for GCA and SCA for traits as sedimentation value and phenol colour reaction suggests that there is presence of both additive and nonadditive gene effects in controlling these traits as reported by Seboka et al., 2009.

The higher value of mean squares for GCA for protein content, sedimentation value, hectolitre weight and phenol colour reaction compared to mean square for SCA indicates the predominance of additive gene action in controlling these traits. In a study conducted by Rahman et al., 2003, additive gene action was predominantly found to be controlling protein content in spring wheat. However, dominance gene action was mainly found to be controlling protein content in a study conducted by Morojele and Labuschagne (2013).

In conformity with our study Morojele and Labuschagne (2013) also found that sedimentation value was mainly controlled by additive gene action. The GCA effects for different quality traits along with mean value of parental lines are shown in Table 2. 
Table.2 Mean performance and general combining ability (GCA) effects for quality traits in wheat

\begin{tabular}{|c|c|c|c|c|c|c|c|c|}
\hline \multirow[t]{2}{*}{ Parents } & \multicolumn{2}{|c|}{$\begin{array}{l}\text { Protein content } \\
(\%)\end{array}$} & \multicolumn{2}{|c|}{$\begin{array}{l}\text { Sedimentation value } \\
(\mathrm{ml})\end{array}$} & \multicolumn{2}{|c|}{$\begin{array}{l}\text { Hectolitre } \\
\text { weight }(\mathrm{Kg} / \mathrm{hl})\end{array}$} & \multicolumn{2}{|c|}{$\begin{array}{l}\text { Phenol colour } \\
\text { reaction }\end{array}$} \\
\hline & $\begin{array}{l}\text { GCA } \\
\text { effect }\end{array}$ & $\begin{array}{l}\text { Parent } \\
\text { mean }\end{array}$ & $\begin{array}{l}\text { GCA } \\
\text { effect }\end{array}$ & $\begin{array}{l}\text { Parent } \\
\text { mean }\end{array}$ & $\begin{array}{l}\text { GCA } \\
\text { effect }\end{array}$ & $\begin{array}{c}\text { Parent } \\
\text { mean }\end{array}$ & $\begin{array}{l}\text { GCA } \\
\text { effect }\end{array}$ & $\begin{array}{c}\text { Parent } \\
\text { mean }\end{array}$ \\
\hline $\begin{array}{l}\text { KAUZ/ALTAR84/3/ } \\
\text { MILAN/KAUZ/4/HU } \\
\text { ITES }\end{array}$ & -0.046 & 11.0 & -0.156 & 31.7 & 0.623 & 74.3 & $0.400 * *$ & 7.6 \\
\hline UP 2762 & 0.069 & 11.0 & $4.789 * *$ & 49.0 & -0.380 & 71.5 & $-0.322^{* *}$ & 4.6 \\
\hline KFA/2*KACHU & -0.106 & 11.7 & $-1.350 * *$ & 46.3 & $\begin{array}{l}1.017 * \\
*\end{array}$ & 74.4 & $-0.600 * *$ & 2.3 \\
\hline Raj 4419 & $0.225^{*}$ & 11.3 & $-0.739 *$ & 47.3 & $0.808^{*}$ & 72.3 & $-0.489 * *$ & 7.6 \\
\hline PBW 729 & 0.196 & 11.7 & 0.344 & 42.3 & 0.645 & 74.3 & 0.094 & 6.0 \\
\hline WH 1187 & 0.136 & 11.4 & $-1.572 * *$ & 42.0 & $-0.863^{*}$ & 71.6 & $0.233^{*}$ & 6.3 \\
\hline HD 2967 & -0.152 & 11.2 & 0.567 & 45.0 & $-0.818^{*}$ & 70.5 & 0.011 & 6.3 \\
\hline DBW 50 & -0.029 & 10.7 & -0.017 & 44.3 & 0.057 & 72.3 & $0.289 * *$ & 6.6 \\
\hline NIAW 1594 & $-0.307 * *$ & 10.2 & $-5.850 * *$ & 25.7 & -0.396 & 72.3 & 0.094 & 7.0 \\
\hline QLD 39 & 0.014 & 11.6 & $3.983 * *$ & 57.0 & -0.694 & 70.8 & $0.289 * *$ & 8.0 \\
\hline SE (gi) & 0.107 & & 0.321 & & 0.385 & & 0.097 & \\
\hline SE (gi-gj) & 0.159 & & 0.479 & & 0.574 & & 0.145 & \\
\hline
\end{tabular}

Protein content of wheat is an important quality traits. The amount of protein in wheat varieties plays an important role in deciding the end use of wheat. High protein wheat varieties are mainly used in preparation of breads while lower protein content in wheat is important for its utilisation in preparation of biscuits, cookies etc.

Intermediate protein content in wheat leads to utilisation of wheat flour for multiple purpose and in India intermediate protein wheat is mainly used for making chapatti. Protein content in wheat generally varies from 10$15 \%$ and depends on both genetic and environmental factors, mainly on availability of nitrogenous fertilisers (Shewry and Hay, 2015).

Only a single parental line Raj 4419 showed significant positive GCA effects for protein content i.e., 0.225 along with high mean value 
of $11.3 \%$. Therefore this line can be used as parent in hybridisation programme to produce transgressive segregants having high protein content. Sedimentation value is also another important traits that determine quality of wheat grains.

The sedimentation test has been designed as a simple and rapid way to estimate the strength of wheat. Varieties with high sedimentation value have high gluten strength and finds their way into utilisation for preparation of bread while those having low sedimentation value hence weak gluten can be used for preparation of cookies, cakes etc.

Hence sedimentation value decides the end use of wheat. In present study two parental lines UP 2762 (4.789) and QLD 39 (3.983) have significant positive GCA effects with high mean values of 49 and 57, respectively.

While line NIAW 1594 have significant negative GCA effects with mean value of 25.7. So these lines can be used as parents to produce wheat varieties suitable for specific purpose. Hectolitre weight is another important quality trait in wheat that decides the recovery of flour after milling and is recognised as an important quality traits by milling industry (Schuler et al., 1995).

KFA/2*KACHU and Raj 4419 have significant positive GCA effects of 1.017 and 0.808 along with high mean value of 74.4 and 72.3, respectively for hectolitre weight. Phenol test in wheat also determines the chapatti making quality of wheat. It usually is an indication of the tyrosinase (Polyphenol oxidase) activity in wheat grains.

Higher activity of tyrosinase leads to darkening of flour and is thought to be unsuitable for chapatti making (Naqvi et al., 2013). Significant negative GCA effects were reported in lines UP $2762(-0.322)$ and
KFA/2*KACHU (-0.600) along with phenol colour reaction value of 4.6 and 2.3 , respectively. These lines having higher per se performance along with significant estimates of GCA effects in desirable direction can be used as parental line in crosses effected with the main aim of bringing about improvement for different quality traits.

The crosses along with their SCA effects and mean values have been depicted in table... Out of total 45 crosses 3,18, 2 and 7 crosses showed significant SCA effects in desirable direction for protein content, sedimentation value, hectolitre weight and phenol content, respectively.

The ranking of specific cross combinations on the basis of their per se performance and SCA effects were depicted in Table 4. Protein content is one of the most important quality trait of wheat. On the basis of both SCA effects and higher per se performance three crosses namely, Raj 4419 x PBW 729, KAUZ/ALTAR84/3/MILAN/KAUZ/4/HUIT ES x DBW 50, UP 2762 x DBW 50 were identified as superior cross combinations.

Similar significant estimates of SCA effects for protein content has been reported by Akram et al., (2011) and Joshi et al., (2016). Similarly for sedimentation value KAUZ/ALTAR84/3/MILAN/KAUZ/4/ HUITES x UP 2762 and UP 2762 x HD 2967 were identified as superior specific combiners.

Similar results has been reported by Esra and Kokasal (2010). For hectolitre weight PBW 729 x DBW 50, Raj 4419 x QLD 39 and for phenol colour reaction Raj 4419 x NIAW 1594, UP 2762 x Raj 4419 were identified as superior specific combiners. Similar results for phenol colour reaction were identified by Singh et al., (2012). 
Table.3 Mean performance and specific combining ability (SCA) effects for quality traits in wheat

\begin{tabular}{|c|c|c|c|c|c|c|c|c|}
\hline \multirow[t]{2}{*}{ Crosses } & \multicolumn{2}{|c|}{ Protein content $(\%)$} & \multicolumn{2}{|c|}{$\begin{array}{l}\text { Sedimentation } \\
\text { value }(\mathrm{ml})\end{array}$} & \multicolumn{2}{|c|}{$\begin{array}{l}\text { Hectolitre } \\
\text { weight }(\mathrm{Kg} / \mathrm{hl})\end{array}$} & \multicolumn{2}{|c|}{$\begin{array}{l}\text { Phenol colour } \\
\text { reaction }\end{array}$} \\
\hline & SCA effect & Mean & $\begin{array}{l}\text { SCA } \\
\text { effect }\end{array}$ & Mean & $\begin{array}{l}\text { SCA } \\
\text { effect }\end{array}$ & mean & $\begin{array}{c}\text { SCA } \\
\text { effect }\end{array}$ & mean \\
\hline $\begin{array}{l}\text { KAUZ/ALTAR84/3/MILAN/ } \\
\text { KAUZ/4/HUITES } x \\
\text { UP } 2762\end{array}$ & 0.011 & 11.2 & $9.894 * *$ & 55.7 & 0.047 & 72.9 & -0.217 & 6.6 \\
\hline $\begin{array}{l}\text { KAUZ/ALTAR84/3/MILAN/ } \\
\text { KAUZ/4/HUITES x } \\
\text { KFA/2*KACHU }\end{array}$ & -0.084 & 10.9 & -1.301 & 38.3 & -0.417 & 73.8 & 0.394 & 7.0 \\
\hline $\begin{array}{l}\text { KAUZ/ALTAR84/3/MILAN/ } \\
\text { KAUZ/4/HUITES x } \\
4419\end{array}$ & -0.301 & 11.1 & $-7.912 * *$ & 32.3 & 1.126 & 75.1 & -0.384 & 6.3 \\
\hline $\begin{array}{l}\text { KAUZ/ALTAR84/3/MILAN/ } \\
\text { KAUZ/4/HUITES } x\end{array}$ & -0.215 & 11.1 & $9.005 * *$ & 50.3 & -1.278 & 72.6 & 0.366 & 7.6 \\
\hline $\begin{array}{l}\text { KAUZ/ALTAR84/3/MILAN/ } \\
\text { KAUZ/4/HUITES x WH } \\
1187\end{array}$ & -0.293 & 11.0 & 1.588 & 41.0 & -0.137 & 72.2 & 0.561 & 8.0 \\
\hline $\begin{array}{l}\text { KAUZ/ALTAR84/3/MILAN/ } \\
\text { KAUZ/4/HUITES x HD } 2967\end{array}$ & 0.180 & 11.2 & $2.449 *$ & 44.0 & -0.049 & 72.3 & 0.116 & 7.3 \\
\hline $\begin{array}{l}\text { KAUZ/ALTAR84/3/MILAN/ } \\
\text { KAUZ/4/HUITES x DBW } \\
50\end{array}$ & $1.073 * *$ & 12.2 & 1.366 & 42.3 & 0.310 & 73.6 & 0.172 & 7.6 \\
\hline $\begin{array}{l}\text { KAUZ/ALTAR84/3/MILAN/ } \\
\text { KAUZ/4/HUITES } x \\
\text { NIAW } 1594\end{array}$ & 0.304 & 11.1 & -1.801 & 33.3 & 0.296 & 73.1 & -0.301 & 7.0 \\
\hline $\begin{array}{l}\text { KAUZ/ALTAR84/3/MILAN/ } \\
\text { KAUZ/4/HUITES x } \\
39\end{array}$ & -0.441 & 10.7 & $5.033 * *$ & 50.0 & -0.805 & 71.7 & $-0.828^{*}$ & 6.6 \\
\hline UP $2762 \times \mathrm{KFA} / 2 * \mathrm{KACHU}$ & 0.175 & 11.3 & $-6.912 * *$ & 37.7 & 0.676 & 73.9 & $1.116^{* *}$ & 7.0 \\
\hline UP 2762 x Raj 4419 & 0.098 & 11.6 & $7.144 * *$ & 52.3 & 0.066 & 73.1 & $-1.662 * *$ & 4.3 \\
\hline UP 2762 x PBW 729 & 0.150 & 11.6 & $-9.606 * *$ & 36.7 & -2.535 & 70.3 & $1.088 * *$ & 7.6 \\
\hline UP $2762 x \quad$ WH 1187 & 0.193 & 11.6 & $-11.023 * *$ & 33.3 & 0.454 & 71.8 & $0.949 * *$ & 7.6 \\
\hline UP 2762 x HD 2967 & -0.382 & 10.7 & $8.505 * *$ & 55.0 & 0.408 & 71.8 & -0.162 & 6.3 \\
\hline UP 2762 x DBW 50 & $0.835^{*}$ & 12.0 & $3.755 * *$ & 49.7 & -1.150 & 71.1 & $0.894 * *$ & 7.6 \\
\hline UP 2762 x NIAW 1594 & -0.404 & 10.5 & $2.588^{*}$ & 42.7 & 1.967 & 73.8 & $0.755^{*}$ & 7.3 \\
\hline UP $2762 \times$ QLD 39 & -0.005 & 11.3 & -0.912 & 49.0 & 0.765 & 72.3 & 0.227 & 7.0 \\
\hline KFA/2*KACHU x Raj 4419 & -0.537 & 10.8 & $-6.717 * *$ & 32.3 & -0.749 & 73.7 & 0.283 & 6.0 \\
\hline
\end{tabular}




\begin{tabular}{|c|c|c|c|c|c|c|c|c|}
\hline KFA/2*KACHU x PBW 729 & 0.285 & 11.5 & $-6.801 * *$ & 33.3 & 0.291 & 74.5 & $0.699 *$ & 7.0 \\
\hline KFA/2*KACHU x WH 1187 & -0.685 & 10.5 & $-6.217 * *$ & 32.0 & -1.031 & 71.7 & $0.894 * *$ & 7.3 \\
\hline KFA/2*KACHU x HD 2967 & -0.063 & 10.9 & $5.977 * *$ & 46.3 & -0.206 & 72.6 & 0.449 & 6.6 \\
\hline KFA/2*KACHU x DBW 50 & -0.263 & 10.8 & $2.894 * *$ & 42.7 & 0.285 & 73.9 & $0.838^{*}$ & 7.3 \\
\hline $\begin{array}{l}\text { KFA/2*KACHU x NIAW } \\
1594\end{array}$ & -0.082 & 10.7 & $3.061 * *$ & 37.0 & 0.496 & 73.7 & $1.033^{* *}$ & 7.3 \\
\hline KFA/2*KACHU x QLD 39 & -0.200 & 10.9 & 0.227 & 44.0 & 1.010 & 73.9 & $0.838^{*}$ & 7.3 \\
\hline Raj 4419 x PBW 729 & $1.161 * *$ & 12.8 & $6.922 * *$ & 47.7 & -1.583 & 72.4 & 0.255 & 6.6 \\
\hline Raj 4419 x WH 1187 & 0.230 & 11.8 & $2.838 * *$ & 41.7 & 0.835 & 73.4 & -0.217 & 6.3 \\
\hline Raj 4419 x HD 2967 & 0.432 & 11.7 & -1.634 & 39.3 & 1.266 & 73.8 & 0.005 & 6.3 \\
\hline Raj 4419 x DBW 50 & -0.084 & 11.3 & $-8.717 * *$ & 31.7 & -0.262 & 73.2 & -0.273 & 6.3 \\
\hline Raj 4419 x NIAW 1594 & 0.067 & 11.2 & $-6.217 * *$ & 28.3 & 0.262 & 73.3 & $-1.745^{* *}$ & 4.6 \\
\hline Raj 4419 x QLD 39 & -0.368 & 11.0 & -1.051 & 43.3 & $2.823 *$ & 75.5 & 0.061 & 6.6 \\
\hline PBW 729 x WH 1187 & -0.180 & 11.3 & -0.912 & 39.0 & 0.898 & 73.3 & $-0.801 *$ & 6.3 \\
\hline PBW $729 \times$ HD 2967 & -0.378 & 10.8 & -0.384 & 41.7 & -0.507 & 71.9 & $1.088 * *$ & 8.0 \\
\hline PBW $729 \times$ DBW 50 & -0.391 & 10.9 & 0.866 & 42.3 & $3.298 *$ & 76.6 & 0.144 & 7.3 \\
\hline PBW $729 \times$ NIAW 1594 & 0.096 & 11.2 & $4.699 * *$ & 40.3 & -0.575 & 72.3 & $-0.662 *$ & 6.3 \\
\hline PBW 729 x QLD 39 & $-0.755^{*}$ & 10.6 & $-4.801 * *$ & 40.7 & 1.179 & 73.7 & -0.189 & 7.0 \\
\hline WH 1187 x HD 2967 & 0.254 & 11.4 & -0.801 & 39.3 & 0.731 & 71.6 & 0.283 & 7.3 \\
\hline WH 1187 x DBW 50 & 0.088 & 11.4 & $4.116^{* *}$ & 43.7 & -0.807 & 71.0 & 0.338 & 7.6 \\
\hline WH 1187 x NIAW 1594 & -0.018 & 11.0 & -0.384 & 33.3 & -1.624 & 69.7 & 0.199 & 7.3 \\
\hline WH 1187 x QLD 39 & 0.601 & 11.9 & $2.783^{*}$ & 46.3 & -0.752 & 70.3 & -0.328 & 7.0 \\
\hline HD 2967 x DBW 50 & $-1.047 * *$ & 9.9 & $-17.356^{* *}$ & 24.3 & 1.350 & 73.2 & $-0.773^{*}$ & 6.3 \\
\hline HD 2967 x NIAW 1594 & 0.391 & 11.1 & $7.447 * *$ & 43.3 & -0.723 & 70.6 & $0.755^{*}$ & 7.6 \\
\hline HD 2967 x QLD 39 & -0.054 & 11.0 & $-9.689 * *$ & 36.0 & -1.388 & 69.7 & $-0.773^{*}$ & 6.3 \\
\hline DBW 50 x NIAW 1594 & 0.258 & 11.1 & $6.061 * *$ & 41.3 & -0.674 & 71.6 & 0.144 & 7.3 \\
\hline DBW 50 x QLD 39 & 0.336 & 11.5 & 0.561 & 45.7 & -1.600 & 70.3 & -0.051 & 7.3 \\
\hline NIAW 1594 x QLD 39 & 0.168 & 11.0 & $-7.939 * *$ & 31.3 & -0.456 & 71.0 & -0.189 & 7.0 \\
\hline SE (ij) & \multicolumn{2}{|l|}{0.359} & \multicolumn{2}{|l|}{1.080} & \multicolumn{2}{|l|}{1.295} & \multicolumn{2}{|l|}{0.327} \\
\hline
\end{tabular}


Table.4 Ranking of good cross combination on the basis of per se performance and their SCA effect in a $10 \times 10$ dialled cross of wheat

\begin{tabular}{|c|c|c|c|}
\hline Character & $\begin{array}{l}\text { Parent with higher per se } \\
\text { performance }\end{array}$ & Good cross combination & Superior common cross combination \\
\hline $\begin{array}{l}\text { Protein } \\
\text { content }(\%)\end{array}$ & $\begin{array}{l}\text { 1) Raj } 4419 \text { x PBW } 729 \\
\text { 2) } \\
\text { KAUZ/ALTAR84/3/MILAN/KAUZ/ } \\
\text { 4/HUITES x DBW } 50 \\
\text { 3) UP } 2762 \text { x DBW } 50\end{array}$ & $\begin{array}{l}\text { 1) Raj } 4419 \text { x PBW } 729 \\
\text { 2) } \\
\text { KAUZ/ALTAR84/3/MILAN/KAUZ/4/HUITE } \\
\text { S x DBW } 50 \\
\text { 3) UP } 2762 \text { x DBW } 50\end{array}$ & $\begin{array}{l}\text { Raj } 4419 \times \text { PBW } 729 \\
\text { KAUZ/ALTAR84/3/MILAN/KAUZ/4/ } \\
\text { HUITES x DBW } 50 \\
\text { UP } 2762 \times \text { DBW } 50\end{array}$ \\
\hline $\begin{array}{l}\text { Sedimentation } \\
\text { value }(\mathrm{ml})\end{array}$ & $\begin{array}{l}\text { 1) } \\
\text { KAUZ/ALTAR84/3/MILAN/KAUZ/ } \\
\text { 4/HUITES x } \\
\text { UP } 2762 \\
\text { 2) UP } 2762 \text { x HD } 2967 \\
\text { 3) UP } 2762 \text { x Raj } 4419\end{array}$ & $\begin{array}{l}\text { 1) } \\
\text { KAUZ/ALTAR84/3/MILAN/KAUZ/4/HUITE } \\
\text { S x } \\
\text { UP } 2762 \\
\text { 2) } \\
\text { KAUZ/ALTAR84/3/MILAN/KAUZ/4/HUITE } \\
\text { S x PBW } 729 \\
\text { 3) UP } 2762 \text { x HD } 2967\end{array}$ & $\begin{array}{l}\text { KAUZ/ALTAR84/3/MILAN/KAUZ/4/ } \\
\text { HUITES x } \\
\text { UP } 2762 \\
\text { UP } 2762 \text { x HD } 2967\end{array}$ \\
\hline $\begin{array}{l}\text { Hectolitre } \\
\text { weight }(\mathrm{Kg} / \mathrm{hl})\end{array}$ & $\begin{array}{l}\text { 1) } \mathrm{PBW} 729 \times \text { DBW } 50 \\
\text { 2) Raj } 4419 \times \text { QLD } 39 \\
\text { 3) KFA/2*KACHU x PBW } 729\end{array}$ & $\begin{array}{l}\text { 1) PBW } 729 \times \text { xBW } 50 \\
\text { 2) Raj } 4419 \times \text { QLD } 39\end{array}$ & $\begin{array}{l}\text { PBW } 729 \text { x DBW } 50 \\
\text { Raj } 4419 \times \text { QLD } 39\end{array}$ \\
\hline $\begin{array}{l}\text { Phenol colour } \\
\text { reaction }\end{array}$ & $\begin{array}{l}\text { 1) Raj } 4419 \text { x NIAW } 1594 \\
\text { 2) UP } 2762 \text { x Raj } 4419 \\
\text { 3) KFA/2*KACHU x Raj } 4419\end{array}$ & $\begin{array}{l}\text { 1) Raj } 4419 \text { x NIAW } 1594 \\
\text { 2) UP } 2762 \text { x Raj } 4419 \\
\text { 3) } \\
\text { KAUZ/ALTAR84/3/MILAN/KAUZ/4/HUITE } \\
\text { S x QLD } 39\end{array}$ & $\begin{array}{l}\text { Raj } 4419 \text { x NIAW } 1594 \\
\text { UP } 2762 \text { x Raj } 4419\end{array}$ \\
\hline
\end{tabular}


The study showed the presence of significant mean squares for GCA for all the traits studied. However significant mean square SCA was present only for sedimentation value and phenol colour reaction while for protein content and hectolitre weight SCA mean square was insignificant. Some of the parental lines showed good general combining ability for more than one quality traits asUP 2762 served as good general combiner for both sedimentation value and phenol colour reaction, $\mathrm{KFA} / 2 * \mathrm{KACHU}$ acted as good general combiner for hectolitre weight and phenol colour reaction and Raj 4419 for protein content and hectolitre weight.

These lines can therefore be used for development of varieties with multiple improved quality traits. On the basis of high per se performance and significant SCA effects in desired direction Raj 4419 x PBW 729, KAUZ / ALTAR84 /3/MILAN/ KAUZ/4/HUITES $x$ UP 2762, PBW $729 \times$ DBW 50 and Raj 4419 x NIAW 1594 were identified as superior cross combiners for protein content, sedimentation value, hectolitre weight and phenol colour reaction.

These crosses can therefore be exploited commercially either in development of hybrid varieties with improved quality traits or in production of superior transgressive segregants which can be used for isolation of superior homozygous lines.

\section{References}

Akram, Z. and Ajmal, S.U. 2011. Combining ability estimates of some yield and quality related traits in spring wheat (Triticum aestivum L. em. Thell). Pakistan Journal of Botany, 43 (1): 221 $-231$.

Esra, F. S. and Kokasal, L. S. 2010. Combining ability in the F1 generation of diallel cross for yield and yield componenets in wheat. Sarhad Journal Agriculture, 23 (4): 937-942.

Joshi, A., Kumar, A., Budhlakoti, V. andBhatt, N. 2019. Heterosis for quality traits in wheat. International Journal of Chemical Studies, 7(6): 404-408.

Joshi, A., Kumar, A., Budhlakoti, V., Bhatt, N. and Prasad, B. 2018. Analysis of variance and estimation of genetic variability parameters for quality traits in bread wheat (Triticumaestivum L. em. Thell) genotypes. International Journal of Chemical Studies, 6(5): 369372.

Joshi, A., Kumar, A., Budhlakoti, V., Bhatt, N. and Tabassum. 2018. Estimation of genetic variability parameters for yield and its components in bread wheat (Triticum aestivum L. em. Thell) genotypes Journal of Pharmacognosy and Phytochemistry, SP5: 87-90.

Joshi, S. K., Sharma, S. N., Singhania, D. L. and Sain, R. S. 2016. Genetic analysis of yield and its component traits in spring wheat. ActaAgronomica Hungarica, 51 (22): 178-195.

Morojele, M. E. and Labuschagne, M. T. 2013. Estimates of genetic parameters for quality of wheat cultivars grown in Lesotho. African Crop Science Journal, 21 (3): $191-199$.

Rahman, M. A., Siddquie, N. A., Alam, M. R., Khan, A. S. M. M. R. and Alam, M. S. 2003. Genetic analysis of some yield contributing and quality characters in spring wheat (Triticum aestivum). Asian Journal of Plant Sciences, 2 (3): 277282.

Schuler, S. F., Bacon, R. K., Finney, P. L. and Gbur, E. E. 1995. Relationship of test weight and kernel properties to milling and baking quality in soft red winter wheat. Crop Science, 35: 949-953.

Seboka, H., Ayana, A. and Zelleke, H. 2009. Combining Ability Analysis for Bread 
Wheat (Triticum aestivum L.). East Africa Journal of Sciences, 3: 87-94.

Shewry, P. R. and Hey, S. J. 2015. The contribution of wheat to human diet and health. Food and Energy Security, 4 (3): 178-202.

Singh, A., Kumar, A., Ahmad, E., Swati and Jaiswal, J.P. 2012. Combining ability and gene action studies for seed yield, its components and quality traits in bread wheat (Triticumaestivum L. em. Thell.). Electronic Journal of Plant
Breeding, 3 (4): 964-972.

Syed Muhammad Saqlan Naqvi, S. M. S., Batool, I., Farooq, M. U., Deeba, F., Hyder, M. Z. and Mahmood, T. 2013. Polyphenol oxidase activities in wheat (Triticum aestivum L.) Grain. Pakistan Journal of Botany, 45(2): 407-407.

Zeleny, L. 1947. A simple sedimentation test for estimating the bread baking and gluten qualities of wheat flour. Cereal Chemistry. 24: 465.

\section{How to cite this article:}

Anjali Joshi, Anil Kumar, Vartika Budhlakoti and Nidhi Bhatt. 2020. Genetic Analysis of Quality Traits in Bread Wheat. Int.J.Curr.Microbiol.App.Sci. 9(02): 929-938.

doi: https://doi.org/10.20546/ijcmas.2020.902.110 